\title{
Acting Out a Traumatic Memory Through Farcical Performance in Enda Walsh's The Walworth Farce
}

\author{
Prof. Sabah Atallah Diyaiy, (PhD), Ruaa Hussein Sofar \\ *University of Baghdad/ College of Education (Ibn Rushd) for Human Sciences
}

DOI: $10.37648 /$ ijrssh.v10i04.038

Received:16 ${ }^{\text {th }}$ November, 2020; Accepted:08 ${ }^{\text {th }}$ December, 2020; Published: 17th December, 2020

\begin{abstract}
Trauma is not an exclusively individualistic phenomenon due to its interrelation with politics, society, history, family and collective memory. Irish history is characterized by repeated and unresolved ordeals that make the traumatic memory lie at the centre of Irish drama. Enda Walsh's The Walworth Farce focuses on the causes and catastrophic consequences of perpetrators' trauma. This article discusses the effects of fetishistic narrative, postmemory, founding trauma and denial on identity, language and psychic stability of the family members. The play is analyzed through Bessel A. van der Kolk and Dominick LaCapra's concepts of the traumatic memory and acting out trauma.
\end{abstract}

Key Words: traumatic memory, acting out, cultural trauma, identity, dysfunctionality, family ties, violence and language functionality.

Irish playwrights' interest in the traumatic memory is due to Irish history that is marked by unresolved traumatic past creating a culture haunted by the "unbiddable, irrepressible, and uncontainable nature" of its traumatic memory that "disrupts linear progress and thus haunts not only the present, but the future also" (Pine,2011, p 16). As an Irish playwright, Enda Walsh's (1967) characters are haunted by their unintegrated traumatic memories that damage their agency in life. The Walworth Farce (2006) was performed by Druid Theatre Company in 2006. It is set in a dilapidated "council flat on the Walworth Road, South London" (2007, p 5) where an Irish tyrannical father, Dinny, has imprisoned his two young adult sons, Blake and Sean, for nineteen years. The traumatised father holds his two sons captive in a farcical performance of a painstakingly fabricated story of their last day in Cork, the south-west of Ireland. He fabricates the truth to escape an unutterable, traumatic memory of two horrible homicides.
The psychiatrist Bessel A. van der Kolk (1943) emphasizes that the intensity of the traumatic experience disrupts the systematic work of the memory system. When a person is exposed to an overwhelming experience, trauma-related memories will not be integrated into any existing meaning scheme that is already established in the mind (van der Kolk and van der Hart, 1995, p 173). Therefore, the individual's traumatic memory will be dissociated from other memories beyond his understanding, conscious awareness and control (Janet, 1925, p 668).

The defence mechanisms of avoidance and denial, against trauma-related stimuli or any subsequent stressful experiences, perpetuate the dissociation of the traumatic memory. However, with the passage of time, the traumatised will suffer from the intrusion of the horrific memory that impairs his ability to cope with the stress of everyday life (van der Kolk et al., 1996, p 305). In addition, avoidance and denial make the traumatised 
carry "the risk of perpetuating trauma-related behavior, such as violence against self and others" which damages the functionality of the individual in his family and society (McFarlane and van der Kolk, 1996, p 30).

Dominick LaCapra (1939), an intellectual historian and literary theorist, defines "Acting out" the traumatic memory as a "repetition compulsion" which is the "tendency to relive the past, to be haunted by ghosts or even to exist in the present as if one were still fully in the past, with no distance from it" (2014, p 142-143). For the language concern, LaCapra explains that the traumatised individual's words "seem to repeat what was said then and function as speech acts wherein speech itself is possessed or haunted by the past and acts as a reenactment or an acting out" (2014, p 90). Moreover, he asserts that if trauma is not perceived as an "object of fixation" and not assimilated as "all-consuming "fate", the traumatised may enter into the phase of working through trauma (LaCapra, 2016a, p 293).

In The Walworth Farce, the setting plays a vital role in reflecting and adding to the overall theme of a disturbed psyche. Walsh places the three characters in a flat of three rooms which belongs to Paddy, Dinny's brother, and his wife Vera. These rooms work as major emotionally arousing stimuli that trigger Dinny's traumatic memories of murdering his brother and sister in law. Therefore, he removes the pictures of Paddy and Vera as he tells Sean: "These pictures of Paddy and Vera on the walls looking down at me, you see them? Asking me questions I can't answer, Sean. With every breath more scared of them" ( $\mathrm{p}$ 69). He even removes "the plasterboard... from the walls" of the rooms and "what remains are the wooden frames beneath" (p 5) in order to terminate the possibility of his memory retrieval. The plasterboard is utilized to create "two wardrobes" (p 5) where the farce's characters exit. Everything in their life is orchestrated and re-arranged for the functionality of the farce that conceals the traumatic past.

The rooms" "decor is at best drab. Everything worn and colourless" ( $\mathrm{p}$ 5). The lack of proper burial of the traumatic past results in an abusive and terrifying household that damages any intimacy and warmth. The traumatised family loses any "psychological, biological, and social equilibrium to such a degree that the memory of one particular event comes to taint all other experiences, spoiling appreciation of the present" moments which results in a "colorless" life (van der Kolk and McFarlane, 1996, p 4). Therefore, the dismal and dark rooms stand for the damaged psyches of the father and his sons.

Dinny plagues Blake and Sean by compulsive, dangerous reenactments of a violent farce. M. H. Abrams and Geoffrey Harpham define farce as a "type of comedy designed to provoke the audience to simple, hearty laughter- 'belly laughs,' in the parlance of the theater"' (2016, p 57). It is characterized by "exaggerated" types of characters positioned "into improbable and ludicrous situations" (2016, p 58). Jessica Milner Davis asserts that one of the five propensities in writing and performing a farce is "to desensitize and codify violence and shock" (2003, p 16). Due to his inability to integrate trauma as part of his autobiography, Dinny desensitises his traumatic memory's horror and codifies the extremity of his violent homicides into a farce. He compels his sons to consider the farcical story as the sole authentic source of their family's history. Problematically, acting out a farce of false memory incessantly for years results in making Dinny amnestic for the real traumatic experience. According to van der Kolk, amnesia of the traumatic experience, a partial or total loss of memory, can be found in "people who have committed murder" (1997, p 249). Nevertheless, the farce refers to Dinny's trauma implicitly due to the traumatic memory's resistance to repression or elimination. Therefore, by acting the farce every day, he unconsciously re-experiences and acts out his traumatic memory.

The family prepares for the beginning of their everyday farcical performance of the last day in Cork by wearing wigs, ironing the clothes and preparing the consumables. Dinny plays an "old tape recorder" of " $A n$ Irish Lullaby"' ( $\mathrm{p}$ 5) indicating the commencement of the farce. The lullaby is an anxiety arousing song for Blake and Sean due to its link to their traumatic childhood and their mother, who is permanently beyond their reach. Dinny utilizes the song, perpetually, as a threatening alarm to remind his sons of their responsibility to act the inescapable farce.

Van der Kolk and Onno van der Hart assert that the traumatic memory is "inflexible and invariable" (1995, p 163) as it blocks any chance of associating subsequent experiences, extracting new meanings or enlarging the mental schemas of the memory system. The inflexibility and invariability of Dinny's traumatic memory make him unconsciously fixated on his trauma. Through the reenactment of the farce, he cannot tolerate any change 
in the performance details, the props and the script. Everything should be repeated exactly every day. Any deviation from the farce's endorsed aspects leads to irrepressible bursts of rage exerted upon the two sons. He compels Sean to go out every morning to buy milk, sliced pan bread, chicken, wafers and one spreadable cheese. However, Sean takes the wrong bag from Tesco supermarket on this day. He becomes "shocked" and in a state of "trepidation" (p 6) when he realizes that. Being raised up by an abusive, fanatic father makes his panic and terror justifiable. Dinny's negative emotions arouse when he realizes that Sean brings sausage instead of chicken:

DINNY (growls to himself). A fecking sausage!? SEAN enters and immediately DINNY swings the frying pan across the back of SEAN's head. SEAN hits the floor fast.

A long pause as DINNY and BLAKE look at SEAN on the floor.

DINNY takes a cup of water and gargles a little. He then spits it out on SEAN's head.

(To BLAKE, calmly.) Get him up and sort him out.

DINNY goes back into the living room and sits in the armchair. He takes his wig off. He takes up a massive bottle of moisturising cream, squeezes some in his hand and aggressively applies it to his face and head. (p 20)

Due to the stress conjured by the discovery, Dinny does not inflict pain and violate Sean's physical integrity only but he tortures him psychologically as well. He humiliates him and violates his dignity by spitting on his head in front of Blake. Dinny moisturises his face and head whenever he is enraged to control his uncontained level of aggression and mitigate his chronic arousal. These posttraumatic symptoms disrupt his ability to function as a responsible caregiver. He cannot build a healthy relationship with his sons as what ties the three is the reenacted past while the present loses its meaning.

Through the farce, Dinny plays the roles of a director, writer, stage manager, critic and an actor of himself in his thirties. Blake plays four roles of three women and one man while Sean plays two male roles. Besides, they play their younger selves as six and five years old. The farce begins with normality as Dinny talks with his brother Paddy, played by Sean, about their unburied mother. ludicrously, their drunk mother was killed by a "wallop" from "a massive dead stallion careering over a hedge" ( $p$ 7-8). Though the farcical story is fictitious, talking about their mother's funeral joyously has a reference to reality. Their felicity is out of their hope to inherit their mother and escape their financial crisis which is the real reason behind Dinny's homicides.

Dinny and Paddy's childhood is marked by poverty and a dysfunctional family of alcoholic parents. In a time of crisis, children need sober and sturdy parents to depend on. The mother was an addicted woman, as even her blood smells whiskey, while the father was mostly "lost in the pub" ( $p$ 31) when his sons faced an intense tribulation. Their parents' drunkenness was mainly due to the staggering poverty as their mother wrote in her will: "you two boys were the only family we ever had, you weren't much but we loved you... though we never got around to showing it on account of the terrible poverty we were under" (p 18). One of the effects of chronic drunkenness is the disturbance of the psychic stability which creates severe depression and disrupts any interest in life. The emotional flatness and carelessness of the parents deprive the children of a functional family of intimacy and stability.

Based on Sigmund Freud's Jokes and their Relationship to the Unconscious, Leslie Smith acknowledges that farce allows repressed thoughts, wishes, needs and impulses, "which the conscious mind would forbid", to be released (1989, p 8). Dinny fails to meet his expectations, fulfil his desire of being a good father and create a healthy life for his sons different from his miserable childhood. Therefore, in the farce, he displays himself as a caring father who does not want his children to see the coffin of their grandmother so that they will not have "nightmares" (p 8). Yet, ironically, he forces his sons to act a farce full of dead bodies and coffins for years.

In the farce, Dinny depicts himself as the only intelligent man who can trick everyone. He depicts Paddy as a man of "miniscule brain" (p 54), which enables him to fabricate his profession and deceive him easily. His fabrication is due to the will's rule that bequeathed the estate to the "the most successful" son (p 18). He justifies the big leap from a painter to a brain surgeon by an inconceivable story of saving a woman's cracking head by pouring "two litres of Coca-Cola" (p 11). This incident induced doctors to give him lectures in brain surgery. His profession refers ironically to his mental disorder. It depicts his repressed desire to assimilate his brain 
operation, which is out of the dissociated traumatic memory.

LaCapra defines "fetishistic narrative" as a kind of narrative that disowns the traumatic experience by reciting the past in "self-serving scenarios" (2014, p 78). The farce's fetishistic narrative, which aims at expunging the traumatic past, is out of Dinny's desire to create a different scenario that serves the current traumatised self. Metaphorically, Nicolas Abraham and Maria Torok compare traumatic memory to a person buried alive in a psychic crypt "without legal burial place" (1994, p 141). When the traumatic memories are silenced and buried in the psychic crypt, the traumatised individuals will resort to "particular forms of obfuscation" in their languages to ward off the revelation of the intolerable pain "to themselves and to the world" (1994, p 105). Accordingly, the speechless terror of trauma will destroy the expressive and communicative power of language from within. Though Dinny entombs his trauma in his psychic crypt, his obscured language in the farce has the indelible scars of his trauma which is metaphorically presented in Paddy's "critical condition":

SEAN AS PADDY. Remember as a little boy that big railing I impaled

myself on... pierced my back?

DINNY. Oh that hole!

SEAN AS PADDY. It just missed the heart, didn't it. When I get too

excited, Dinny, I fall over...

DINNY. Do ya?

SEAN AS PADDY. I do! Blood stops racing to the head... I collapse.

DINNY. Collapse!? Good Lord!

SEAN AS PADDY. Doctor says one day I might never wake up. (p 9)

Unconsciously, giving Paddy a critical condition in the farce is out of his silenced sense of guilt and shame. Being the only beneficiary of the will by killing his sibling and escaping to live in his flat are like stabbing a brother in his back and causing him a hole that will make him collapse and die.

By murdering Paddy and Vera, Dinny betrays all the familial ties. His feelings of guilt and remorse are presented in the farce as Paddy tells him: "You were never there for me" ( $p$ 10). That is why he constantly instructs Blake to take care of his younger brother when they act their younger selves. He does not want them to be like him and his brother. His inability to articulate the real events without obfuscation is because the traumatic experience "is outside the frameworks of normal social reality and thus outside the linguistic and other symbolic tools we have at our disposal for making sense of the world. It is unspeakable, inexpressible" (Edkins, 2002, p 246).

LaCapra's concept of "postmemory" refers to "the acquired memory of those not directly experiencing an event" (2004, p 108). This concept has a strong presence in The Walworth Farce. As Irish history is marked by violent centuries of colonisation, catastrophes and political turbulence, many generations could not work through the extremity of their cultural trauma. Their trauma left "indelible marks upon their group consciousness, marking their memories forever, and changing their future identity in fundamental and irrevocable ways" (Alexander,2012, p 6). Accordingly, Irish descendants, unconsciously, acquired their ancestors' traumatic memories with social and political ideologies. They carried a disturbing psychic legacy. Dinny's words about Ireland and London are marked by the atrocities of British colonisation rather than by the discourses of twenty-first century. His language is haunted by the polarities of colonisation, like victim and victimizer, civilized and barbaric, good and evil and powerful and weak, as he carries his ancestors' memories. When he talks about Ireland and Cork, he uses the language of a fairy tale: "A jewel with the majestic River Lee ambling through it, chopping the diamond in two before making its way to murkier climes ... towards the poisonous Irish Sea for example" (p 16). The Irish Sea is described as toxic just because it links Ireland and Britain.

When Dinny talks about London and its people, he tells a horror story of cannibals and swindlers who want to annihilate Irish people. London is depicted as full of "Deadly, pitiful places that even the rats have abandoned, the cockroaches have done cockroaching and all that's left is London people" ( $p$ 16). Its weather is illustrated as dark and gloomy echoing its inhabitants who are "So criminal and violent" as they "eat their young" and they are "like nothing more than skinning an Irishman halfway" ( $p$ 16). Through Dinny, Walsh shows the danger of altering a postmemory of historical events according to the subjectivity of the present self. Irish history is marked by a delicate web of complex political events, traumatic experiences and marginalisation which makes any alteration result in terrible repercussions.

402 
Dinny uses his postmemory of cultural trauma as a founding trauma which is a kind of "trauma that carries a powerful affective charge and may be transformed or transvalued in ideological ways" (LaCapra,2016b, p 394). LaCapra suggests that a founding trauma "can become invidious and self-centered, lending itself to some very dubious uses and abuses" and "to justify intensified surveillance and data collection" or for "enabling or even authorizing the use of terror and traumatization" (2016b, p 395). Whenever Dinny notices a development of the rebellious behaviour of his sons, he terrorises them by exaggerating his postmemory. He presents to them an enemy, the Londoners, that can unite them against the outside. He uses his postmemory ideologically to create an escape route for himself, to escape being their real enemy.

When Sean questions the validity of the farcical story, "Is any of this story real?", and Blake wants "to go back to Ireland" (p 29-30), Dinny loses his mental stability. Their words function as stimuli that unhinge his mind and trigger the denied traumatic memory. Therefore, his language fails him as he articulates the same words repetitively unable to complete the sentence: "And the sea, Blake. The sea, the sea, the sea, the sea, the sea ..." (p 30). As he gets his psychic stability back, he repeats his fabricated, horrible story of emigration: "I run the same race a million Irishmen ran. But pockets full of new money and Paddy's keys in my hands with Walworth Road a final destination" but London's "towers or flats or big gate" did not welcome him and looked at him "Like a little rat caught in a drain" (p 30). As he goes on, he asks Blake to narrate the hardest part of the story to guarantee that it is deeply ingrained in his psyche. With extreme trepidation and tears, Blake completes the story: And then the people. They come out from houses and shops and

they're after you. Their skin, it falls to the ground and them bodies

running you down and wanting to tear you

to shreds. From the river

they're coming. They come up from the

ground. The concrete snaps

open and the bodies are up fast. And they're

all snapping teeth and

grabbing hands they have. Run faster and

faster until a thousand

green windows reaching up into the sky and

Paddy's flat right at the top and it's calling you. Take to the stairs with the other flats teeming

out the bodies wanting to grab you down and get ya. The stairs and

your speed .... (p 31-32)

Reciting the terrifying story of emigration shatters Blake's mental equilibrium. His inability to proceed is due to his belief in Dinny's fictitious story and his amnesia concerning the reality of the last day in Cork. Sean is able to complete the story without difficulties as he vividly remembers the events of that day but he cannot face an oppressive, tyrannical father. Dinny claims "sovereignty over the body and its freedom, over life and death" which is, according to Gabriele Schwab, "a form of dehumanization" (2010, p 154). Their subjectivities are rendered to objects in the grip of their father who deals with them like puppets at his disposal. Therefore, he destroys the concept of home as a place of affection, security and comfort which marks the outside as better than the inside.

As the story of the farce unfolds, it seems that Dinny and his wife Maureen fools Paddy and Vera by bringing them to the house of Mrs Cotter's family, whom Dinny works for as a painter, pretending to be theirs. They aim at making Paddy believe that Dinny is a successful man so he can get the money of the will. When the owners of the house arrive holding a coffin, the farce becomes complicated as a new story of conspiracy and murder starts to reveal. Blake plays Mrs and Mr Cotter's roles, Eileen and Jack, while Sean plays Eileen's brother role, Peter. The latter kills his father with the aid of Jack to divide his money between them without Eileen's knowledge. Dinny's traumatic memory damages his imagination and undermines his ability to construct a story that does not match his traumatic experience.

Dinny should justify to both Cotter family and his brother the presence of another family in the house. On one hand, he makes Paddy believe that Cotter's family are his coworkers. On the other hand, he convinces Eileen that Paddy is insane because he "was bitten and infected with a terrible snake venom" and "his infected brain has started an unrelenting rot" (p 54). Moreover, bringing him to their house is justified by the claim that he wants to mitigate his brother's condition who believes that Cotter's family are "all brain surgeons intent on removing that snake venom from his miniscule brain" ( $p$ 54). Eileen and Peter are profoundly affected by the strong bond of 
love Dinny has for his brother. These fabricated stories are constructed to keep the ghost of his past, with all the accompanying feelings of guilt, shame and loss, silenced and prohibit its resurrection.

The play takes an abrupt shift when a stranger, Hayley, enters with the right Tesco bag of groceries that Sean confusingly leaves behind. She is a black Tesco employee from south London. Nicholas Grene says that one of the features of Irish drama is when "into the room there enters a stranger, and the incursion of that extrinsic . . potentially transforms the scene" (2004, p 52). Hayley's presence disrupts their rigorous and subtle performance. Her love confession to Sean functions as a catalyst that enables him to summon his courage and force his father to open his psychic crypt. According to Sean, she is his only hope to help him escape the life-long incarceration and monotonous life of his traumatised father to pursue his own vision of good life. Blake gets away from her as his father's terrifying words about Londoners have their echoes in his mind.

Dinny asks Hayley two questions only: "Is there a cooked chicken and sliced pan in there?" and "Can you cook?" (p 40), without trying to know who she is. He solves the problem of having a stranger by obliging her to perform Maureen's role. When she decides to escape, his negative emotions arouse again:

DINNY suddenly pounces on her and grabs her by the throat,

pinning her to the door. He takes her bag and throws it to one side.

SEAN and BLAKE come out from the kitchen and stand by, watching.

DINNY. Don't scream now.

HAYLEY, terrified, looks towards SEAN. (p 51)

Dinny's inability to regulate his behaviour in intense situations is because the traumatic memory arouses the traumatized individuals' "negative emotions (fear, anxiety, anger, and panic)" only and; therefore, they "either overreact and threaten others, or shut down and freeze" (van der Kolk and McFarlane,1996, p 13).

As the farcical performance proceeds, what happens in the farce have its resemblance in real life. Jack gets irritated when he finds out that Peter changes his mind about swindling Eileen's share of the inheritance. Peter's alteration of the plan is out of listening to Dinny's passionate words about his brother which troubles him by a sense of guilt and pangs of conscience. Therefore, "BLAKE AS JACK suddenly smacks SEAN AS PETER hard across the face. A little too hard" which makes "SEAN, taken aback, dives at BLAKE. The two fall to the ground and start to fight each other" (p 55-56). Out of his trepidation, Blake makes the performance escalate to a real fight. Firstly, he is afraid that Sean will leave him alone in the house and break down their family's rituals by escaping with his beloved.

Secondly, Blake's trepidation is out of his belief that Hayley will kill them as he is profoundly affected by his father's stories about the Londoners:

BLAKE (quietly). Were you talking to her about us? Are you trying to

find ways to get us down to the streets? Send the little girl up and

the door starts banging with more bodies wanting to get us. Are

you turning your back on me, Sean?

DINNY stands at the kitchen entrance looking in on the two of them.

SEAN. I wouldn't do that. I couldn't be alone outside without you,

Blake.

BLAKE. But you're wanting me to kill Dad, aren't you, Sean? We kill

Dad, break the story, step outside like you've got it all planned ...

but then you walk away from me with her. (p 56-57)

LaCapra's concept of transgenerational transmission of trauma coincides with Abraham and Torok's concept of "phantomatic haunting" (1994, 166). Both concepts demonstrate that the phantoms of the parents' psychic crypt can make their offsprings manifest symptoms of a trauma that they have not experienced directly. Blake's generalisation of the threat, in which he displays all the Londoners as Irish's slayers, is out of the hauntology of his father's phantom that perpetually disturbs his psyche. Moreover, he even threatens to kill Sean if he tries to ruin the repetitive enactment of the story. He is unable to listen to the real events that Sean tries to tell because his acute trauma is more complex than that of his father.

The play reaches its climax when Dinny desires to listen to Sean's memories of the last day in Ireland. He asks him to start from the point that they were playing in Mrs Cotter's garden as two savage boys. Sean refuses to recite the same fabricated story. Instead, he exposes the 
truth of the nonexistence of Mrs Cotter family as he and Blake were playing in their own garden. The beginning of that day was of dreams about a bright future as they were "lying on the grass" and dreaming of "being an astronaut" and "a bus driver" (p 58). Sean tries to break down his father's defence mechanisms of avoidance and denial and bring him to reality in order to end the agony of his shattered family.

The second part of the story is an explanation of the bloodstains that ruined Blake and Sean's hopes of a pure and bright future:

There's shouting from inside the house. You and Uncle Paddy screaming at each other. Fighting over Granny's money even before she's stuck in the ground. Aunty Vera crying her cries real high like a baby crying. Your voice so much bigger than Uncle Paddy and him saying, 'No, Dinny, no please, Dinny!' (Slight pause.) And then we hear Mammy screaming, Dad. . Blake won't go inside 'cause he's frightened of what he might see. But I do. I do go inside. And Mammy grabs me and spins me around fast so I can't see . . . but I see Uncle Paddy and Aunty Vera on the ground and I see you standing in the corner with blood all over your hands. There's blood on your hands and a kitchen knife, I'm sure of it . . .. And Mammy kisses you and says, 'Leave, now', and sets you free. (p 58-59)

Sean's words trigger Dinny's traumatic memory. Dinny "is affected by what SEAN says" but "Momentarily" ( $\mathrm{p}$ 59) as he tries to deny it again. He cannot bear the retrieval of his traumatic memories. He justifies the nineteen years of compulsive reenactments of a fabricated story with one sentence only: "I'm keeping you and Blake safe" ( $p$ 59). He finds himself in a situation that makes nothing possible to alleviate his dejection except his relationship with his role in the farce.

Laurence J. Kirmayer explains that some traumatised individuals are reluctant to recall their traumatic past: "When the costs of recollection seem catastrophic for self or other, memory may be sequestered in a virtual (mental) space that is asocial, a space that closes in on itself through the conviction that no telling will ever be possible" (2016, p 189). Dinny decides to disclaim Sean's narrated story and insist on the credibility of his own story as he violently "grabs SEAN and throws him out into the sitting room" (p 61) to complete the performance of the farce.

Dinny's crime is subsumed under crimes of passion as it matches David Lester and Gene Lester's explanation of "frustration-aggression" crime (1975, p 197). Frustration raises when a "barrier prevents a person from satisfying a drive or need which has been aroused" (1975, p 197). This barrier can have different forms like the "individual's lack of competence", the loss of someone, political and economic issues and many other environmental obstacles that may arouse frustration (1975, p 197). Problematically, when a high level of frustration occurs, it may end with aggression and "An aggressor can turn his hostility either outward toward other people or inward upon himself (through suicide, self-mutilation, or long-term self-destructive behaviors like alcoholism)" (1975, p 198-199). During the 1980s, many Irish people were frustrated due to their inability to provide a decent life for their families. Dinny's last day in Ireland was in the 1980s. As a period of famine, destitution, violence and economic collapse, his only hope to end his frustration was to get the money of inheritance to end the misery of his family. Because he was not the most successful brother to get the inheritance, his negotiation with Paddy and Vera ended with aggression towards others as he commits horrible crimes.

The farce reaches its climax by the disclosure of Dinny's lies. As Sean reveals the unspeakable trauma in reality, in the farce, Paddy discovers the reality of the house property. Vera describes Dinny's fraud as "using a time of grief to rob a man of his rightful inheritance!" (p 65 ). These words show Dinny's sense of guilt and shame. The language of the farce is mainly marked by trauma because the dissociated traumatic memory becomes "a center of gravity around which the symbolic order is condemned to circle, without ever being able to hit it" (Fink, 1997, p 28).

When Sean insists on his inability to complete the performance, Dinny "presses the knife in harder into SEAN's throat" (p 68) and tries hard to put his traumatic memory into the symbolic order but he fails. According to van der Kolk and Alexander C. McFarlane, to overcome the pathological level of trauma, the individual should "label and evaluate the meaning of sensations and affective states", distinguish "present from past" and "interpret social cues in the context of current realities rather than past events" (1996, p 18). To transform the traumatic memory into autobiographical narratives, 
Dinny needs to restructure the experience into a linear narrative and reduce its negative emotional effects. In contrast, he finds himself unable to articulate the scene of the murder as a story with beginning, middle and end. He only narrates the end of the murder scene from the perspective of how Sean witnessed the crime rather than from his own position: "You looking in at Paddy and Vera dead on the floor like you said. My hand shaking. Real blood on the carpet ... I'm about to leave but I see you looking at me. Looking for answers, aren't ya? I turn and go. I go" (p 69). His mental instability compels him to construct short sentences with basic nouns and verbs in the present tense instead of past tense. Moreover, he does not articulate his sense of guilt, shame or loss.

During the nineteen years, Dinny entombs the guilty, criminal and post-traumatic self inside his psychic crypt without time or place. However, it keeps haunting his psychic life and damages his language functionality from within. The intrusion of the traumatic memory obliges him to confront the silenced self which makes him long for his pre-traumatic self who "was a good man", as he tells Sean (p 68). His mind is unable to assimilate how a righteous man committed a crime out of anger and rage to be the man who possesses the diabolical spirit rather than the Londoners. LaCapra asserts that to work through trauma, losses should "be specified or named . . . so that they may be given a proper burial" (2014, p 69). For Dinny, it is hard to accept a loss not only of people but of his innocent self as well.

Van der Kolk and McFarlane elucidate that what marks an experience as overwhelming for some people is their confrontation "with aspects of the human capacity for evil that they had never before imagined" (1996, p 8). For Dinny, Sean's insistence to reveal the truth forces him to confront the catastrophe of his self's capacity for evil rather than others'. This extremely overwhelming and intense encounter makes him "clutches at his head in real pain" ( $\mathrm{p}$ 69). Therefore, he decides to return to the state of denial rather than acceptance and immerse in his fabricated world again. He informs Sean that the farce is his only "truth, nothing else matters" (p 70).

Dinny goes back to act out the farce but the condition is totally different now. Being threatened by Sean makes his strategy of domination and subjugation through direct threat inefficacious. Therefore, he insinuates in Sean's mind a different idea:

DINNY. To kill me would only turn you into your dad. Isn't that what you're thinking, Sean? Answer me, boy. A long pause.

So you're not going to kill me then?

A pause.

Hah?

SEAN doesn't answer. (p 70)

He tells Sean that committing a parricide would not happen in "The Waltons" cartoon (p 70) in order to terminate such an idea from his mind. He compares Blake and Sean to characters in an animated series believing they are still children. As the line between past and present is blurred, he is stuck in the day of his trauma unaware of the passage of time.

Blake and Sean finish the farcical performance for their own purposes. For Sean, it is for the sake of setting Hayley free as his father promises him. After overhearing the conversation of truth revelation, Blake's performance is aimed at ending the farce forever. He wants to create an escape-route for Sean and Hayley to share a life of love and intimacy outside the flat. The last scene of the farce is acted with trepidation and aggression as Blake deludes Sean by his aim to kill Hayley. Therefore, Sean acts with a hidden knife in his pocket as a caution strategy. The farce ends with Jack poisoning the sauce of chicken and killing Peter and Eileen to get the inheritance money. He is unaware that Peter has already poisoned his beer. Vera appears as a fallen woman who betrays Paddy with Peter; therefore, she dies poisoned with him. Furthermore, Paddy dies due to his critical condition while Dinny grabs all the money and flees to London. At the end of the farce, Dinny says "For what are we ... if we're not our stories?" and he gets an incisive answer from Blake: "We're the lost and the lonely" ( $p$ 82). Blake's sentence summarizes the consequences of growing up in a family haunted by a traumatic memory.

To end the performance, Blake asks Hayley to lock up Sean in the wardrobe so that he will not stop him. While acting the last scene with his father, Blake "fires the knife into DINNY's back" to avenge his uncle. Moreover, he "pulls out the knife, turns DINNY towards him quickly and stabs him in the stomach hard" (p 83) as an act of revenge for ruining their lives. He asks Hayley to open the wardrobe and tricks Sean by pretending that he will kill her. Sean "runs from the wardrobe and drives his knife into BLAKE's stomach" (p 83). Like the end of the acted farce, the family's story ends with horrible crimes. When Sean figures out his brother's good intention, he "takes the knife out of BLAKE's stomach. Blood pours 
onto the floor" ( $\mathrm{p}$ 83) and Blake kisses him and says "Now leave, love" (p 84). Blake repeats what Maureen did and said to Dinny at the end of that day. The last day in Ireland is repeated in London. Sean becomes the murderer of his brother and his mind is disturbed by the death of two members of his family at the same time. He locks the door after Hayley's departure and loses himself in acting out all the roles of the farce alone.

\section{CONCLUSION:}

In The Walworth Farce, Walsh shows the capability of the farce to desensitise the darkest episodes of the character's traumatic past in a codified language and with a metaphorical depth. Dinny's traumatic experience of frustration-aggression crime and his emigration refer to the overwhelming experiences of 1980s Ireland. His fetishistic narrative that is reenacted compulsively through farce results in a dysfunctional family responsible for the polyvictimization and traumatisation of its members. The play examines the effects of utilizing unresolved cultural trauma as a founding trauma on the psyche of the younger generation, represented by Blake and Sean. The play's subtlety and depth display the repercussions of not working through cultural trauma and the tremendous effects of its transformation into a founding trauma.

\section{WORKS CITED}

Abraham, Nicolas, and Maria Torok (1994). The Shell and the Kernel: Renewals of Psychoanalysis. Ed. and trans. Nicholas T. Rand. Vol. 1. Chicago: Chicago UP.

Abrams, M. H., and Geoffrey Galt Harpham (2016). Comedy. In A Glossary of Literary Terms (pp. 56-59). 11th ed. USA: Cengage Learning.

Alexander, Jeffrey C (2012). Trauma: A Social Theory. Cambridge: Polity Press.

Davis, Jessica Milner (2003). Farce. London: Taylor \& Francis.

Edkins, Jenny (2002). "Forget Trauma? Responses to September 11.” International Relations, 16 (2): $243-256$.

Fink, Bruce (1997). The Lacanian Subject: Between Language and Jouissance. New Jersey:

Princeton UP.

Grene, Nicholas (2004). The Politics of Irish Drama: Plays in Context from Boucicault to Friel. UK: Cambridge UP.

Janet, Pierre (1925). Psychological Healing: A Historical and Clinical Study. Trans. Eden Paul and Cedar Paul. New York: The Macmillan Press.

Kirmayer, Laurence J (2016). Landscapes of Memory: Trauma, Narrative and Dissociation. In Paul Antze and Michael Lambek (Ed.), Tense Past: Cultural Essays in Trauma and Memory (pp. 173-198). New York: Routledge.

LaCapra, Dominick (2014). Writing History, Writing Trauma. USA: The Johns Hopkins UP.

--- (2004). History in Transit: Experience, Identity, Critical Theory. Ithaca: Cornell UP.

--- (2016a). Representing the Holocaust: History, Theory, Trauma. Ithaca: Cornell UP.

--- (2016b). “Trauma, History, Memory, Identity: What Remains?” History and Theory, 55: 375-400.

Lester, David, and Gene Lester (1975). Crime of Passion: Murder and the Murderer. Chicago: Nelson Hall.

Pine, Emilie (2011). The Politics of Irish Memory: Performing Remembrance in Contemporary Irish Culture. UK: Palgrave Macmillan.

Schwab, Gabriele (2010). Haunting Legacies: Violent Histories and Transgenerational Trauma. New York: Columbia UP. Smith, Leslie (1989). Modern British Farce: A Selective Study of British Farce from Pinero to the Present Day. UK: The Macmillan Press.

Walsh, Enda (2007). The Walworth Farce. London: Nick Hern Books.

van der Kolk, Bessel A., and Onno van der Hart (1995). The Intrusive Past: The Flexibility of Memory and the Engraving of Trauma. In Cathy Caruth (Ed.), Trauma: Explorations in Memory (pp. 158-182). USA: The Johns Hopkins UP.

van der Kolk, Bessel A., et al (1996). Dissociation and Information Processing in Posttraumatic Stress Disorder. In van der Kolk et al. (Ed.), Traumatic Stress: The Effects of Overwhelming Experience on Mind, Body, and Society (pp. 303-327). New York: The Guilford Press. 
van der Kolk, Bessel A., and Alexander C. McFarlane (1996). The Black Hole of Trauma. In van der Kolk, et al. (Ed.), Traumatic Stress: The Effects of Overwhelming Experience on Mind, Body, and Society (pp. 3-23). New York: The Guilford Press.

Van der Kolk, Bessel A. Traumatic Memories (1997). In Paul S. Appelbaum, et al. (Ed.), Trauma and Memory: Clinical and Legal Controversies (pp. 243-260). New York: Oxford UP.

McFarlane, Alexander C., and Bessel A. van der Kolk (1996). Trauma and Its Challenge to Society. In van der Kolk et al. (Ed.), Traumatic Stress: The Effects of Overwhelming Experience on Mind, Body, and Society (pp.24-46), ed. van der Kolk, et al. New York: The Guilford Press.

van der Kolk, Bessel A., and Alexander C. McFarlane (1996). The Black Hole of Trauma. In van der Kolk, et al. (Ed.), Traumatic Stress: The Effects of Overwhelming Experience on Mind, Body, and Society (pp. 3-23). New York: The Guilford Press. 